\title{
How does an ANT approach help us rethink the notion of site?
}

Document Version

Accepted author manuscript

Link to publication record in Manchester Research Explorer

\section{Citation for published version (APA):}

Yaneva, A., \& Mommersteeg, B. (2019). How does an ANT approach help us rethink the notion of site? In A. Blok, I. Farias, \& C. Roberts (Eds.), The Routledge companion to actor-network theory (1st ed., pp. 306-317).

Routledge.

\section{Published in:}

The Routledge companion to actor-network theory

\section{Citing this paper}

Please note that where the full-text provided on Manchester Research Explorer is the Author Accepted Manuscript or Proof version this may differ from the final Published version. If citing, it is advised that you check and use the publisher's definitive version.

\section{General rights}

Copyright and moral rights for the publications made accessible in the Research Explorer are retained by the authors and/or other copyright owners and it is a condition of accessing publications that users recognise and abide by the legal requirements associated with these rights.

\section{Takedown policy}

If you believe that this document breaches copyright please refer to the University of Manchester's Takedown Procedures [http://man.ac.uk/04Y6Bo] or contact uml.scholarlycommunications@manchester.ac.uk providing relevant details, so we can investigate your claim.

\section{OPEN ACCESS}




\title{
How does an ANT approach help us rethink the notion of site?
}

\author{
Albena Yaneva and Brett Mommersteeg
}

As early as the 1990s, Science and Technology Studies (STS) scholars have engaged with urban and architectural themes. These first studies looked at town planning as a technology and the city as an 'enormous artefact' (Aibar \& Bijker, 1997), the invisible networks that shape big metropolises (Latour \& Hermant, 1998), and urban obduracy and change (Hommels, 2005). Meanwhile, the sociotechnical analysis of innovations introduced by Madeleine Akrich and Bruno Latour in the late 1980s (Akrich, 1987, 1992), which had inspired work on design, focused on how technical objects generate specific modes of social, political and juridical organisation. This scholarship gradually led to further explorations in industrial (Dubuisson \& Hennion, 1995, 1996) and engineering designs (Bucciarelli, 1994; Ferguson, 1992; Henderson, 1999; Law, 2002; Vinck, 2003).

Yet, architectural design remained a completely unmapped epistemological territory of STS analysis until 1996. In that year, Michel Callon released a seminal paper advocating the importance of Actor-Network Theory (ANT) as a methodological perspective for deepening our understanding of architecture. Arguing that 'the results of the anthropology of science and technology are transportable to the field of architectural studies,' he set an agenda for the decades to come (Callon, 1996, 1997). The first STS-inspired empirical study of architectural practice appeared on the pages of Social Studies of Science in 2005 (Yaneva, 2005), followed by studies devoted to the ethnography of architectural practices (Houdart \& Minato, 2009; Latour \& Yaneva, 2008; Loukisass, 2012; Yaneva, 2009a; Yaneva, 2009b). These works redescribed the socio-material dimensions of designing architects and set an ANT-inspired research agenda. The studies of cities through an STS-informed approach multiplied as well, as witnessed in a number of edited volumes (Blok \& Farías, 2016; Farías \& Bender, 2010; Guggenheim \& Söderström, 2011, see also Färber, this volume) and special issues of Science Studies journals (Yaneva \& Guy, 2008; Yaneva, 2011) and architectural journals (Yaneva, 2018).

When the ANT methodology started travelling outside its privileged domains of action science, engineering, medicine and markets - the list of non-humans began to expand from the repertoire of microbes, scallops, bacilli, metro systems and other technical objects to include Portuguese ships, sick bodies, African elephants, drug addicts and amateurs of music. This list has since stretched to include an even more varied assembly of non-humans commonly found in architectural and urban worlds: Architectural renderings (Houdart, 2008), 
scale models (Yaneva, 2005), city plans (Zitouni, 2010) and maps (Nadaï \& Labussière, 2013; Vertesi, 2008), for instance. However, as the ANT methodology has travelled to increasingly more domains, site itself has not yet been subject to the scrutiny of an ANT enquiry. In this short article, we will prepare the groundwork for one possible account of site.

\section{'Site' as an object of (architectural) analysis}

Despite its prominent status in design and in architecture, site has received little attention in architectural theory. More often than not, notwithstanding the technical and professionaloriented literature on 'site analysis' and 'site planning' (Lynch \& Hack, 1984), site is conflated and grounded in other notions that have played a larger role in architectural discourse such as context, region, locality, setting, territory and land or landscape; or it is explored through historical examples of architectural projects without conceptual reflection. While in practice, sites are subject to a variety of analyses, observations, visits, tests, studies, plans and reports, bursting with different problematics like noise pollution, constraints, histories, traffic and logistics, trees and vegetation, layers of soil, waste, neighbours, visual impacts, among others, in theory, sites have been simplified and digested in mainly three ways: As tabula rasa, as natural facts and as social constructions.

Typically, sites are characterised as an external reality, a physical space with varying physical attributes out there, or within a series of representations, appearances and social relations superimposed over that external reality. In the modernist discourse of architecture, the site loses these characteristics as they are actively ignored. The physical and social aspects of the site are removed from the scenography in order to posit an abstract, idealised understanding of design that eschews the specificity and particular conditions of a site in search of the universal conditions for design (Redfield, 2005). Thus, the aim was to remove all pre-existing qualities and values of a site, to arrive at a zero point, a tabula rasa, from which to build.

By reducing site to a tabula rasa free of influences and attachments, and focusing solely on the products and objects of architecture, modernism's effects on thinking about site in architecture are substantial and far-reaching. In fact, all the subsequent discussions of site can be understood as reactions to the modernist discourse, circling around two foci: Do buildings fit into their sites, the context, constraints and parameters? Or do they emerge from the site, as a set of influences and determinants?

Responding to the modernist idea of a tabula rasa site, such follow-up discussions of site present it either in terms of primary or secondary qualities. ${ }^{1}$ For the former strand of analysis, site is no longer a nuisance to suppress, but a resource to actively draw from as inspiration. As Ian McHarg (1971) argues, for instance, in the tradition of genius loci, design ought to extract, draw out the values that are hidden within the physical and natural aspects of a site; site, still a passive resource, is nevertheless an important aspect for design.

Here, the site, while present, acts as the architectural representative of Nature, a mute objectivity whose hidden values require human actions in order to be drawn out. The natural values of a site are captured by technical processes, in their purity, not yet spoilt by the social (Lynch \& Hack, 1984; McHarg, 1971). This understanding of a site qua Nature is commonly found in landscape architecture (Meyer, 2005), drawing from 19th-century garden theory (Hunt, 1992). By upscaling site to a multi-scalar complexity of interconnected forces, ranging from the biological and physical to the economic and the political, recent landscape architecture theory highlights the continuity of a site across scales and domains. Still, akin to site planning, it remains by and large a process by which such interconnected forces can be captured, rationalised and turned into an objectified pattern (Gissen, 2010; McQuade \& 
Allen, 2011; Mostafavi \& Doherty, 2010). Even as a totality of interacting forces, both 'natural' and 'human' site remains a set of facts out there: Either as a rough ('wild,' 'bucolic') set of values or as a smooth, rationalised pattern.

The third interpretation of site moves onto secondary qualities: We jump from the objective to the subjective. Within this body of literature, we are led from a phenomenological understanding of place (Beauregard, 2005; Hornstein, 2011) to the socially constructed nature of a site (Burns, 1996; Burns \& Kahn, 2005; Kahn, 1998). Site is thus reduced to a perspectivism, where its physical nature is lost behind partial individual perspectives and social relations. Here, the discussion of site coincides with the increasing importance of place, region and context in architectural theory, and acts as an architectural avatar for these concepts, mimicking the theoretical discussions of space and place in the 'spatial turn' in geography. Rendered as different kinds of 'appearances,' site, as a concept in this body of literature, becomes interchangeable with its conceptual avatars, and loses its architectural specificity.

From this all-too-brief exploration of the concept of site in architectural theory, we can see that site has not been able to escape the effects of the Modernist influence. Either it is a blank slate whereupon, in a 'double-click,' buildings emerge without influence; or it acts as the architectural equivalent of Nature, as a stubborn set of facts (always set against the urban, the city, which are human artefacts); or, alternatively, as a social construct (always set against the impossibility of 'true' objectivity). In other words, site functions as a mediating interface between architecture, nature and society, caught between objective reality and subjective perception or social relations - bifurcated between primary and secondary qualities.

In architectural theory, the concept of site has thus followed a similar trajectory as notions of space and place, from an absolute empty container, to a physical and external 'outside,' to a product of social relations or subjective perceptions. Yet, if we follow the process of planning and architectural design, site appears as situated in the midst of reports, analyses, visits, technologies, measurements, photographs and tests; site is actively dissected and observed, folded and unfolded - more than a container, an object or a social construct. Thus, site emerges as a set of movements to follow.

\section{Movements of Site-ing}

If we follow design and construction processes, how often do we encounter a site simply as nature 'out there': Physical, static and passively awaiting the intervention of an adventurous designer? Conversely, how often is a site a pure social construction: A cultural product that is fabricated alongside another cultural construction, a building or infrastructure? Against the stubbornness of a site qua set of facts, and against the relativity of a site qua social construct, we are interested in moving beyond the two, not by adding them as two absolutes, but by focusing on what is frequently forgotten in the literature: How site matters in design, planning and construction processes, and the very work of accounting for site, working with it, according to it. We will call this specific work site-ing; this includes the work of placing and spacing simultaneously the built (a building or an urban infrastructure) and the site itself.

In what follows, we will zoom into specific situations where the work of site-ing becomes visible, and is made visible with ANT tools. We will trace the site-ing moves as ways of rearranging and repositioning the elasticity of the malleable urban networks of a city. Site-ing appears as a major work of questioning simultaneously the site and the built, nature and culture, building technologies and meaning. Unpacking these moves of site-ing will also illustrate the work that is needed by an ANT-informed ethnographer to unravel the complex agency of sites in design making, and to recalibrate, subsequently, the techniques of the 
ethnographic enquiry. We will reflect on the figure of the ethnographer, and will account for the recalibration of her specific trajectory, practices and interview techniques as they constitute the work of site-ing the ethnographer.

\section{Site-ing a building}

In 2014, the then Chancellor of the Exchequer of the UK government George Osborne announced in the Autumn Statement a new scheme called the 'Northern Powerhouse,' aimed to enhance growth in the North of England. At the 'heart' of the scheme is 'Factory,' an arts and cultural building in Manchester designed by the Office for Metropolitan Architecture (OMA) ${ }^{2}$, which would act as the 'home' of the Manchester International Festival (MIF), a peripatetic arts festival, and a 'cultural anchor' for the regeneration of St. John's neighbourhood in Manchester city centre. ${ }^{3}$ Factory's site is situated in a historically complex location, full of imposing constraints, from 'listed' historic buildings, neighbouring urban elements to the future developments of St. John's. Due to this, planning Factory has shown to be a laborious movement of site-ing.

We first encounter the complexity of the site in the rhetoric used by the designers in their presentations of the project to different audiences. During a recent presentation by the head of OMA's UK office, Carol Patterson presented the site as an active and surprising participant in design: When they had visited the site in Manchester, they realised that, instead of the simple box shape in a simple location that was stipulated in the competition brief, how complicated and enfolded that site was. It was only through the process of planning and development, which unfolds these features of the site, and that they confront its complications.

In her presentation, Carol explained that 'there were a lot of things that interweaved between our site: some of the cultural history, the music history and the future'; the site, they discovered, was full of historical artefacts and references that play an important role in the future of the site, and the building-to-be. ${ }^{4}$ The site, as suggested, is 'interwoven' with features that need to be untangled and unfolded. Following the movement of site-ing requires the crafting of a new context, the constrained act of site expansion and redistribution. Through these movements, we witness the Factory site growing and being defined at the same time that the building is outlined in design.

Expected to be completed by 2021, Factory provides us a rich opportunity to see the movements of site-ing up close. We can still witness the movements, the expansion and contraction of the Factory site, and the continual back and forth process from one locale-ofpractice to another (that is, planning offices, design and engineering firms, acoustics labs, public consultations, client's headquarters, among others), as it expands to other entities, accommodating their agency into the larger aggregate that Factory site will become. Site-ing is made in between many locales and aims to 'anchor' the complexities of the building site, by untangling and retying the threads, through negotiating and recalibrating the connections that it enters into.

One simple way to explore these movements is to slowly move through the planning documents, which do not have a simple representative function, but give us access to the specific knowledge practices and modes of organisation involved in site-ing work (Hull, 2012; Riles, 2006). Here, as particular 'inscription devices' (Latour \& Woolgar, 1986), the various injunctions of the site are unfolded. We do not only have various viewpoints onto a virtual building, but the documents themselves (and the studies therein) unearth (literally sometimes) these various locales and connected entities within the site. Each document acts like 'oligoptica' (Latour, 2005; Latour \& Hermant, 1998) that capture different aggregates, 
entities and locales, whether the composition of soil, flow of traffic or the various histories of the site, and never against some common substantial nature. They not only unfold the multilayered strata of the site that gathers actors as mediators (Asdal, 2015), but the documents transport the Factory site to other locales-of-practice, modifying it as they move.

In other words, not only are there many different aggregates within the one place, but this site travels to and gathers different locales-of-practice into it: From OMA's office in Rotterdam to LevelAcoustic's acoustic laboratory in Eindhoven to the city council rooms in Manchester, Planit's UXB (unexploded bombs) labs in York, the warehouses of the 1800s, to BuroHappold's offices in Bath. In all these movements, something is gained, something is added to the living aggregate that the Factory site is about to become.

However, this is not merely a process of unfolding, but - to reiterate - of re-crafting connections and aggregating them into a new context. Site-ing becomes a movement that reconfigures connections to achieve a single voice: Turning the many different aggregates and locales that need to be visited in order to recollect the Factory site for design. In other words, the site cannot remain a pure multiplicity, but requires closure as a practical necessity for planning permission and to be used in design (Figure 29.1).

Returning to Carol's presentation, we hear her develop a narrative through the confluence of histories specific to Factory's site: Important features that not only impinge on the design, but are also enrolled in the trajectory of the building-to-be in order to allow it to move. It is situated within the old headquarters of Granada TV, sitting atop the brick-arches of the Grade II-listed Colonnaded Railway Viaduct, whose now disused railway lines lead to a non-listed yet important industrial Bonded Warehouse that abuts the site to the East. Thus, rising above the Manchester and Salford Junction Canal, an industrial canal from 1839, the site is full of recalcitrant constraints that have become enlisted in its trajectory. It is important

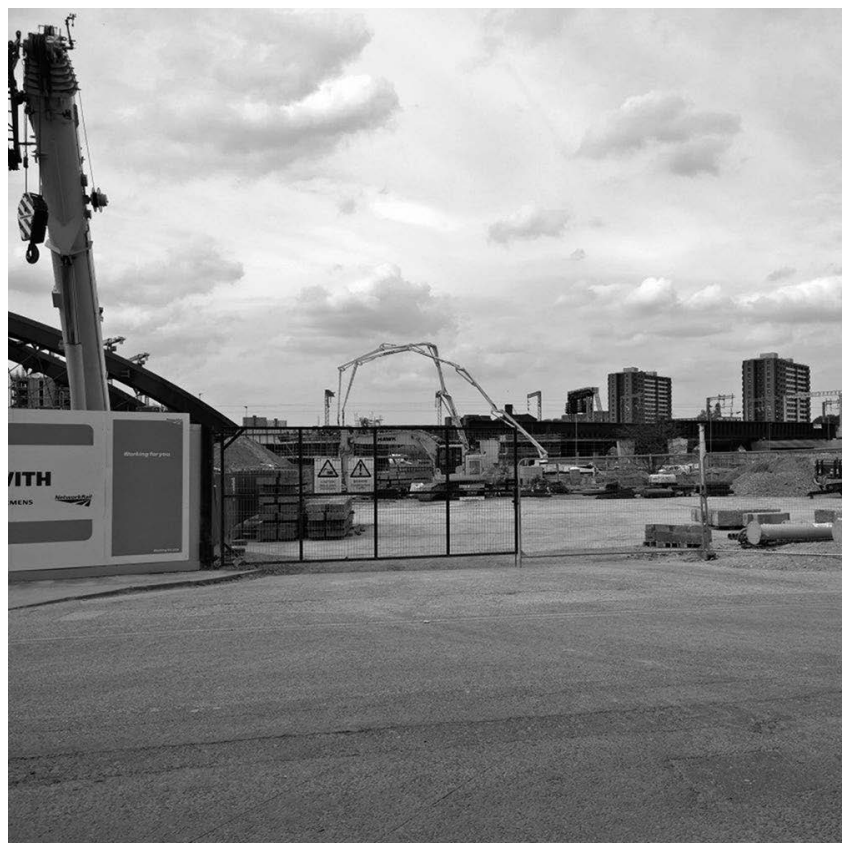

Figure 29.1 Factory, OMA - building site in Manchester (Authors' Own) 
to note, though, that this history does not rest in the background as a grand narrative to justify the site's importance. Instead, it is a crafting of context that actively unfolds in the construction and recollection of the Factory site. With each document and each urban feature, another actor is invited into the fold of the site, expanding its reach, enrolling others; thus, we witness the composition of site. As planning unfolds, its aim is to 'compose' a site, not in contradistinction to the context, but simultaneously with it.

At the groundbreaking ceremony, which took place on the site of Factory during MIF months later, Rem Koolhaas informs a crowd of Mancunians, in response to a question about Manchester's heritage, that, yes, nostalgia serves a purpose, but only up to a point. ${ }^{5}$ Site-ing is neither a process of collecting a series of facts about the site, nor is it a way to extract the spirit of a place that pre-exists. It entails work that gathers actors and locales of practice into a single voice for two reasons. First, as a rhetorical device, the site-ing work composes a site, which makes an argument for the building; it is a way of doing words with things. Secondly, it folds in a specific way the contours of the site into an active 'origami' that also reacts to the other givens and constraints in the design and planning of the project. While these enlisted actors need to be negotiated into the project, they are nevertheless recalibrated along its trajectory.

In both these senses, we see how site-ing is not a way of finding breathing room in a dense urban location, but it is rather about tracing a project trajectory to witness the right composition of the site for design. In other words, it is not a passive ground that a building fits into, or a determining context, but a composition that shifts and modifies as new entities are enrolled or subtracted. Moving through the planning documents, as they travel from one locale of design and construction to another, following designers as they engage in grasping the complexity of the site and composing it as a full-blown participant in the project, we can trace the manifold of the Factory site, the necessity to unfold, to multiply and then to aggregate it again in order for the project to succeed. The planning documents and design movements reveal site not as a resource that exists in potential, waiting to be realised, nor as an exercise in cultural fiction, but as a living 'trajectory of actualisation, ${ }^{6}$ a process of crafting, redefining and aggregating a new context.

Amidst the site as a composition that shifts, how is the ethnographer supposed to navigate through this shifting field, to walk on this shaking ground of dispersed locales-of-practice? As we will now unfold, there is more to this than the tracing of planning documents and designers' moves, in that the ethnographer participates in the very work of site-ing.

\section{Site-ing the ethnographer}

Unlike other standard ethnographic studies, less time was spent in this field. However, a few specific techniques helped intensify the presence of the ethnographer, maximising the time spent. The work of site-ing made the ethnographer move from one locale-of-practice (of design, planning and construction) to another, equipped with camera, notebook and tape recorder. Meanwhile, the participants in the ethnographic study continued to work in these various locales, surrounded by their objects, documents and tools, knowing that another colleague was being interviewed at that moment and that a specific part of their practices was being revealed, documented and ethnographically captured. Their movements sometimes overlapped with the ethnographer's moves and this led to the synchronic visibility of all the participants in the study, a form of co-presence ${ }^{7}$ that maintained the transparency of the dispersed locales of the ethnographic enquiry.

It is well known from STS' laboratory ethnographies that knowledge production is embedded in local environments (Merz, 2006). As Knorr-Cetina (1995, p. 151) argues: 'If construction 
is wrapped up in bounded locales, the ethnographer needs to "penetrate the spaces" and the stream of practices from which fact construction arises.' While in other ethnographies where we have spent years living immersed in an office (OMA, Rotterdam) or frequently travelling to visit a practice (FOA, London), this study included the work of site-ing. When the ethnographer gained access to the 'stream of practices' of the Factory-making, most of the ethnographic interviews ${ }^{8}$ were conducted as locale-based interviews in a specific place of practice and included elements of immersive observation.

As an ethnographic interviewing technique, this contextual inquiry implied going to the participants' offices to gather qualitative data in order to capture the natural setting of specifically situated design, engineering and planning practices, and witness how the participants work, asking specific site-related, object-focused questions about what they were doing and why. Observing different actors and questioning them in their environments was paramount for bringing important details about their practice to light. Locale-based interviews in design studios, planning and engineering offices, city government offices and public presentations acted as site-ing devices recalibrating the ethnographer's presence and the presence of others.

Only rarely would an interview have a script and a fixed scenario, a sitting plan that would not change. Instead of engaging in a directed question-and-answer interviewing style, a static situation where everyone and everything is seated, 'in place,' the ethnographer spends time exploring the specific locale-of-practice, wandering, pointing to specific objects, touching documents, folders and screens that were currently in use, thus collecting a series of specific features about the building-making. This 'wandering around a locale-of-practice' type of interview prompted a number of questions emerging from the contextual specificity of the practice that unfolds and the socio-material circumstantiality of that locale-of-practice, streaming right from the world of objects, instruments and documents. That is, the ethnographer also sites herself according to the rhythm of the enquiry that will lead to the composition of the Factory site.

Site-ing, as an ethnographic strategy, is thus a way of "establishing co-presence. ${ }^{9}$ Site-ing is not a rhetorical device that aims to convince. Instead, it is almost the opposite: Cracking 'open' the black box of studios, labs and planning offices, fissuring practices typical for this locale into many different associations. It implies that nothing is still; site-ing moves us all forward through new connections and additions. The ethnographic interview reminds us of the site-ing process outlined earlier in the example of the Factory site composition through planning documents and tracing design moves. Through this site-ing process, we do not capture the world of the locale-of-practice in toto, but only fragments of it. ${ }^{10}$ It entails work that gathers people, documents, bodies and skills and sites them according to the ANT ethnographic enquiry: The interview itself becomes a way of producing words with things. By the strolling in the locale, the stream of new questions, the interviewees wandering around the ANT ethnographer and the dance of the objects activated 'on the go,' site-ing folds in a very specific experiential, but always fragmented way the contours of the locale-of-practice, hosting the interview, in an active relational spatial 'origami.'

Much as in design practice, it is the 'active' nature of the locale that gathers talking objects, instruments, scripts and actors together, to the extent that the place of ethnography is not a passive backdrop for an ethnographer (just as site is not a tabula rasa), but rather 'activates' the interview; the entire collective assemblage of enunciation speaks. Neither the actors nor the researcher speaks; rather, the building-making processes are spoken through them. The site-ing interviews are thus reminiscent to the work of composing a musical piece, where all participants contribute to finding the right tones, the good arrangements and activate new connections, which, when aggregated together in the rhythmic flow of a stream 
of practice, will generate a full-fledged set of tones that make sense. In these interviews, the locales-of-practice site us all through co-presence; the stream of the interview experience operates symmetrically through the researcher, and the actors convoked, as well as the devices and questions that activate it further.

Walking through different locales-of-practice where the site-ing is preformed, we stroll, visit, stop and discuss specific objects, the interview stages change as we move, and different objects appear and disappear from the misty scenes. Stopping by, site-ing around, and engaging in discussions that last longer than a question-and-answer sharp rhythm allows creating specific settings where the objects can talk, and the interviewees will talk with the objects to the researcher via the objects, and in many different locales-of-practice. Thus, the ethnography of the Factory-making is a walk on its own, a long and interrupted walk capturing 'occasions' or events. In this walking process, both interviewer and interviewees are situated, their boundaries blurred and the 'being-in' of a passive space turns into an active regime of 'being-with' many locales-of-practice that unfold. If site-ing interviews involve strolling within a locale-of-practice and with it, walking with the Factory site relies on exploring and walking with many locales-of-practice in a pluriverse ethnographic journey of enquiry. In each of them a different feature of Factory site is extracted and added to the composition. This also sites the ANT ethnographer within the unfolding dynamics of design and construction, and vibrant urban processes that are all interconnected. In addition, it makes the ANT ethnographer complicit to site-ing, that is, to the composition of the Factory site, lending to it some stability and coherence.

It is impossible to witness all the locales-of-practice: Only so many fragments from projects, rhythms and time spans are witnessed. Not being able to visit all of the locales-ofpractice, to be present there at the same time and in the key moments of decision-making, we abandon the ambition of establishing connections or comparisons with other building projects, architectural firms and urban developments. Instead, bringing experiences from different locales of the Factory-making together, assembling information from site-ing interviews and walking as a way to recreate simultaneity and synchronicity, revealed the multi-actorial and multifaceted nature of design, and allowed the ethnography to capture a building world as it opens itself up to scrutiny, and as it takes us, as Donna Haraway (1991) would say 'in the belly of the monster.'

\section{Multi-Site-ing}

If the site is never 'out there' but always requires the work of site-ing, grasping the site in design and construction processes also demands the tedious work of an ANT ethnography that constantly sites the researcher. This is the double work of multi-site-ing and re-site-ing, of going back and forth between the different locales-of-practice, over and over again, from which a notion of an 'ethnographic site' is generated as something that remains the same throughout all these movements.

Just as the site is neither 'there' ready to accommodate a building, nor appears as a purely social or material construction, so is the work of the ANT ethnographer: None of her interviews happen 'on-the-spot.' The locales-of-practice are not ready at hand, waiting to be studied. They all require the active work of site-ing and re-site-ing the researcher; each of them provides partial access to the composition of the Factory site as an object of analysis. They have to congregate. It is only when assembled into an ethnographic account that the ethnographer's work begins to 'resemble' the designers' and planners' site-ing work. Following the pitfalls of site-ing the researcher within this shifting ground of composing the Factory 
site, nothing is stable or could simply begin from a tabula rasa. The ethnographer begins in the middle, as it were. It becomes even impossible to allude to the seemingly similar concept of multi-sited ethnography developed by George E. Marcus (1995). With ANT in hand, confronting objects and devices that act back, facing unknown sources of agency, and immersed within contextual mutations that shape as we move, we are rather part of an enquiry of 'multi-locality.' The scope of this ANT enquiry goes far beyond a notion of 'multisitedness' as every single 'site' (termed here locale-of-practice) is also produced as a subtle and 'multi-local' work of composition.

None of the participants in the design and planning process of the Factory can grasp its site totally on the spot. The ANT ethnographer is just as myopic. It is through the act of joining the site-ing of the Factory that the ethnographer becomes an integral part of folding its spatial 'origami' further, along with many designers, planners, engineers and other participants in the different locales-of-practice. The Factory site composition becomes the ethnographer's own locale. Each move adds new tones. All of them eventually achieve stabilisation (albeit fragile): A Factory site gradually emerges as we reach the end of this account about its making. Coherent and stable, the site is required to eventually host a building that stands heavy and unbearably durable. Composed and sound, the ethnographer eventually completes her account that is light and inevitably re-writeable by other researchers who can also take up an enquiry into the question of site.

\section{Notes}

1 This old philosophical divide is most clearly articulated by John Locke in Essay Concerning Human Understanding (1997 [1689]). Primary qualities refer to the brute matter extended in space, whereas secondary qualities refer to phenomenal, subjective attributes. But it is also the foundation for modern Occidental philosophy as the split between appearances and reality, the phenomenal and noumenal worlds, as well as the split between being and becoming. For the diagnosis of this divide, see Alfred North Whitehead's lectures in The Concept of Nature (2015 [1920]), what he has called the 'bifurcation of nature.'

2 OMA is a Dutch architectural firm, based in Rotterdam, founded in 1975 by Dutch architect Rem Koolhaas and Greek architect Elia Zenghelis, along with Madelon Vriesendorp and Zoe Zenghelis. It is one of the leading practices in the world today. See Yaneva's ANT-study of design in the making (2005 and 2009a) based on material from this practice.

3 OMA. (October, 2016). "Design and Access Statement: Factory". Manchester, UK: Manchester City Council.

4 Patterson, C. (June 2017). Manchester Architect's Symposium: Factory.

5 Koolhaas, Rem, Ellen Van Loon, and Hans Ulrich Obrist. (July, 2017). The Factory Panel: Spaces for Culture.

6 See Gilles Deleuze's work on Bergson (1991 [1966]) for a philosophic account of the 'trajectory of actualisation,' the production of the new, as it differs from the realisation of pre-existing possibilities.

7 Anne Beaulieu (2010) put forward the concept of co-presence as a way to shape fieldwork. If other authors underline the desirability of physical co-location as a requisite for ethnographic investigation, Beaulieu shifts the focus on achieving co-presence by emphasising that interaction is a potentially rewarding but precarious achievement (Goffman, 1957), and that physical presence is not equivalent to availability for interaction (Goffman, 1971). While physical co-location can be a resource for participants, it is not in itself a sufficient criterion for co-presence. Co-presence decentralises the notion of space without excluding it. Beaulieu argues also that the possibility of copresence might be established through a variety of modes, physical co-location being one among others. Co-presence as a starting point enables a more symmetrical treatment of forms of interaction.

8 For a discussion on ethnographic interviews, see: James Spradley, The Ethnographic Interview, 1979, Wadsworth and John Van Maanen, Tales of the Field: Writing Ethnography, Chicago: Chicago University Press, 2011. 
9 Per Beaulieu's understanding of co-presence as an interactive accomplishment by participants and ethnographers alike that does not share the unidirectional and ocular-centric connotations of witnessing, or interrogating.

10 For a discussion about the problematic of contexts and wholes in cultural anthropology and ANT, see Tsing (2010). In our account of the Factory 'site,' we see the congregation of many wholes that come together, but not as 'parts' that fit within a greater 'whole' that encompasses them. Nevertheless, at the end of the planning process, there needs to be a relatively stable 'site' for the building to be granted planning approval, and for the building to be built, and likewise, the ethnographer composes an account that is more or less coherent, without assuming to have captured its object 'wholly.'

\section{References}

Aibar, E. \& Bijker W.E. (1997) Construct a City: The Cerdà Plan for the Extension of Barcelona. Science, Technology \& Human Values 22(1), 3-30.

Akrich, M. (1987) Comment décrire les objets techniques? Techniques et Culture 9, 49-64.

(1992) The De-Scription of Technical Objects. In Shaping Technology/Building Society. (Bijker, W. \& Law, J., eds.), MIT Press, Cambridge, pp. 205-224.

Asdal, K. (2015) What Is the Issue? The Transformative Capacity of Documents. Distinktion: Scandinavian Journal of Social Theory 16(1), 74-90.

Beaulieu, A. (2010) From Co-location to Co-presence: Shifts in the Use of Ethnography for the Study of Knowledge. Social Studies of Science 40(3), 453-470.

Beauregard, R. (2005) From Place to Site: Negotiating Narrative Complexity. In Site Matters: Design Concepts, Histories and Strategies. (Burns, C. \& Kahn, A., eds.), Routledge, Great Britain, pp. 39-58.

Blok, A. \& Farías, I. (eds.) (2016) Urban Cosmopolitics: Agencements, Assemblies, Atmospheres. Routledge, Great Britain.

Bucciarelli, L.L. (1994) Designing Engineers. MIT Press, Cambridge.

Burns, C. (1996) On Site: Architectural Preoccupations. In Drawing/Building/Text. (Kahn, A., ed.), Princeton Architectural Press, New York, pp. 146-167.

Burns, C. \& Kahn, A. (2005) Why Site Matters. In Site Matters: Design Concepts, Histories and Strategies. (Burns, C. \& Kahn., A., eds.) Routledge, Great Britain, pp. Vii-xxix.

Callon, M. (1996) Le Travail de la Conception en Architecture. Situations, Les cahiers de la recherche architecturale 37(1), 25-35.

Deleuze, G. (1991 [1966]) Bergsonism. (Tomlinson, H. \& Habberjam, B., trans.), Zone Books, Brooklyn, NY.

Dubuisson, S \& Hennion, A. (1995) Le design industriel, entre création, technique et marché. Sociologie d'art 8, 9-30.

- (1996). Le Design: L'objet dans l'usage. Presses des Mines, Paris.

Farías, I. \& Bender, T., (eds.) (2010) Urban Assemblages: How Actor-Network Theory Changes Urban Studies. Routledge, New York, NY.

Ferguson, E. (1992) Engineering and the Mind's Eye. MIT Press, Cambridge.

Gissen, D. (2010) Territory: Architecture Beyond Environment. John Wiley \& Sons, London.

Goffman, E. (1957) Alienation from Interaction. Human Relations 10(1), 47-59. . (1971) Relations in Public: Microstudies of the Public Order. Basic Books, New York, NY.

Guggenheim, M. \& Söderström, O., (eds.) (2010) Re-shaping Cities: How Global Mobility Transforms Architecture and Urban Form. Routledge, New York, NY.

Haraway, D. (1991) Situated Knowledges: The Science Question in Feminism and the Privilege of Partial Perspective. In Simians, Cyborgs and Women: The Reinvention of Nature, (Haraway, D., ed), Free Association Books, London, pp. 183-201.

Henderson, K. (1999) On Line and on Paper: Visual Representations, Visual Culture, and Computer Graphics in Design Engineering. MIT Press, Cambridge.

Hommels, A. (2005) Studying Obduracy in the City: Toward a Productive Fusion between Technology Studies and Urban Studies. Science, Technology \& Human Values 30(3), 323-351.

Hornstein, S. (2011) Losing Site: Architecture, Memory and Place. Ashgate, England.

Houdart, S. (2008) Copying, Cutting and Pasting Social Spheres: Computer Designers' Participation in Architectural Projects. Science Studies 21(1), 47-63.

Houdart, S. \& Minato C. (2009). Kuma Kengo: An Unconventional Monograph. Éditions Donner Lieu, Paris. 
Hull, M. (2012) Government of Paper: The Materiality of Bureaucracy in Urban Pakistan. University of California Press, Berkeley.

Hunt, J. D. (1992) Gardens and the Picturesque: Studies in the History of Landscape Architecture. MIT Press, Cambridge.

Kahn, A. (1998) From the Ground Up: Programming the Urban Site. The Harvard Architectural Review 10, 54-71.

Knorr-Cetina, K. (1995) Laboratory Studies: The Cultural Approach to the Study of Science. In Handbook of Science and Technology Studies. (Jasanoff, S., Markle, G.E., Peterson, J.C., \& Pinch, T., eds.) Sage Publications, Inc., Thousand Oaks, CA.

Latour, B. (2005) Reassembling the Social: An Introduction to Actor-Network-Theory. Oxford University Press, Oxford.

Latour, B. \& Yaneva, A. (2008) Give Me a Gun and I Will Make Every Building Move: An ANT's View of Architecture. In Explorations in Architecture: Teaching, Design, Research. (Geiser, R., ed) Birkhäuser, Basel, pp. 80-89.

Latour, B. \& Hermant, E. (1998) Paris, ville invisible. Empécheurs de penser rond, Paris.

Latour, B. \& Woolgar, S. (1986) Laboratory Life: The Construction of Scientific Facts. 2nd edn. Princeton University Press, Princeton, NJ.

Law, J. (2002) Aircraft Stories: Decentering the Object in Technoscience. Duke University Press, Durham, NC.

Locke, J. (1997 [1689]) An Essay Concerning Human Understanding. (Woolhouse, R., ed.) Penguin Books, London.

Loukissas, Y. A. (2012) Co-Designers: Cultures of Computer Simulation in Architecture. Routledge, New York.

Lynch, K. \& Hack, G. (1984) Site Planning. 3rd edn. MIT Press, Cambridge.

Marcus, G.E. (1995) Ethnography in/of the World System: The Emergence of Multi-Sited Ethnography. Annual Review of Anthropology 24, 95-117.

McHarg, I. (1971) Design with Nature. Doubleday \& Company, New York.

McQuade, M. \& Allen, S. (2011) Landform Building: Architecture's New Terrain. Lars Muller Publishers, Baden.

Merz, M. (2006) Différenciation interne des sciences: constructions discursives et pratiques épistémiques autour de la simulation. In La fabrique des sciences. Des institutions aux practiques. (Leresche, J.-P., Benninghoff, M., Crettaz von Roten, F., \& Merz, M., eds.) Presses polytechniques et universitaires romandes (PPUR), Lausanne, pp. 165-182.

Meyer, E. (2005) Site Citations: The Grounds of Modern Landscape Architecture. In Site Matters: Design Concepts, Histories and Strategies. (Burns, C \& Kahn, A., eds.) Routledge, Great Britain, pp. 92-130.

Mostafavi, M. \& Doherty, G. (2010) Ecological Urbanism. Lars Muller Publishers, Baden.

Nadaï, A. \& Labussière, O. (2013) Playing with the Line, Channelling Multiplicity: Wind Power Planning in the Narbonnaise (Aude, France). Environment and Planning D: Society and Space 31 (1), 116-139.

Redfield, W. (2005) The Suppressed Site: Revealing the Influence of Site on Two Purist Works. In Site Matters: Design Concepts, Histories and Strategies. (Burns, C. \& Kahn, A., eds.) Routledge, Great Britain, pp. 185-222.

Riles, A. (Ed.). (2006) Documents: Artifacts of Modern Knowledge. University of Michigan Press, Ann Arbor.

Spradley, J. (1979) The Ethnographic Interview. Wadsworth, California.

Tsing, A. (2010) Worlding the Matsutake Diaspora, or Can Actor-Network Theory Experiment with Holism? In Experiments in Holism: Theory and Practice in Contemporary Anthropology. (Otto, T. \& Bubandt, N., eds.) Wiley-Blackwell, Oxford, pp. 52-76.

Van Maanen, J. (2011) Tales of the Field: Writing Ethnography. Chicago University Press, Chicago.

Vertesi, J. (2008) Mind the Gap: The London Underground Map and Users' Representations of Urban Space. Social Studies of Science 38(1), 7-33.

Vinck, Dominique (Ed.). (2003) Everyday Engineering: An Ethnography of Design and Innovation. MIT Press, Cambridge.

Whitehead, A.N. (1920) The Concept of Nature. Cambridge University Press, Cambridge.

Yaneva, A. (2011) Traceable Cities. City, Culture and Society 3(2), 87-89.

. (2009a) The Making of a Building: A Pragmatist Approach to Architecture. Verlag Peter Lang, Germany. 
- (2009b) Making the Social Hold: Towards an Actor-Network Theory of Design. Design and Culture 1(3), 273-288.

- (2005) Scaling Up and Down: Extraction Trials in Architectural Design. Social Studies of Science 35(6), 867-894.

Yaneva, A. (Ed.). (2018). Bottega. [Special Issue] Ardeth. 2.

Yaneva, A. \& Guy, S. (Eds.) (2008) Understanding Architecture, Accounting Society: A Dialogue of Architectural Studies and Science and Technology Studies. [Special Issue]. Science Studies 21(1).

Zitouni, B. (2010) Agglomérer. Une anatomie de l'extension Bruxelloise (1828-1915). Brussels University Press, Brussels. 